\title{
SIGNIFICANCE OF AGRITOURISM IN TOURIST TRIPS OF THE ACADEMIC YOUTH IN POLAND IN THE LIGHT OF SURVEY RESEARCH
}

\author{
${ }^{1}$ Wioletta KAMIŃSKA, ${ }^{2}$ Mirosław MULARCZYK \\ 1,2Institute of Geography, Jan Kochanowski University in Kielce, Poland \\ 'kaminska@ujk.edu.pl, ${ }^{2}$ miroslaw.mularczyk@ujk.edu.pl
}

\begin{abstract}
The aim of this article is to determine the significance of agritourism in tourist trips of the academic youth in Poland. The primal material was obtained from surveys conducted among 1000 students from 5 academic centres. 712 filled questionnaires were received, 639 of which were qualified for the following research procedure. Criteria adopted for the purpose of this research allow assessing that tourist activity of the surveyed was at a low level. The majority of students is not interested in spending their free time in agritourist farms. Thesis claiming that a higher interest in agritourism was shown by the students with low tourist activity relative to their peers characterised by a high activity was not confirmed.
\end{abstract}

Key words: agritourism, tourist activity, academic youth.

DOI: https://doi.org/10.17721/2413-7154/2017.77.41-47

UDC: 338.23

\section{СОЦІОЛОГІЧНЕ ДОСЛІДЖЕННЯ ЗНАЧЕННЯ АГРОТУРИЗМУ ДЛЯ ТУРИСТИЧНИХ ПОДОРОЖЕЙ СТУДЕНТСЬКОї МОЛОДІ У ПОЛЬЩІ}

\author{
'Віолетта КАМІНСЬКА, ${ }^{2}$ Мирослав МУЛЯРчИК \\ 1,21нститут географії, Університет Яна Кохановського, Кельще, Польща \\ 'kaminska@ujk.edu.pl, ${ }^{2}$ miroslaw.mularczyk@ujk.edu.pl
}

\begin{abstract}
Анотація: Метою статті $\epsilon$ визначення значення агротуризму у туристичних подорожах студентської молоді у Польщі. Первинний емпіричний матеріал для дослідження було отримано шляхом анкетування 1000 студентів 35 вищих навчальних закладів. Було отримано 712 заповнених анкет, 639 з яких були визначені придатними для подальшого дослідження. За допомогою критеріїв, розроблені для цього дослідження, було встановлено загальний низький рівень туристичної активності респондентів. Більшість студентів не зацікавлені проводити свій вільний час шляхом відвідування відпочинково-господарських ферм. Гіпотеза про вищий інтерес до агротуризму у студентів з низькою загальною туристичною активністю у порівнянні зі студентами з високою загальною туристичною активністю не було підтверджено.
\end{abstract}

Ключові слова: агротуризм, туристична діяльність, студентська молодь.

DOI: https://doi.org/10.17721/2413-7154/2017.77.41-47

UDC: 338.23

\section{Introduction}

A dynamic development of tourism in Poland and globally is observed at the verge of 20 th and $21^{\text {st }}$ centuries. The increasing number of tourists is an indication of this trend. According to the United Nations World Tourism Organisation's data, in 2014 the number of international tourists globally reached the level of 1.138 million, and between 1957 and 2009 the size of international touristic movement increased 36-fold (Durydiwka 2009). The Polish in 2015 participated in 39.9 million domestic tourist trips as the Ministry of Sports and Tourism estimates. Thus, it can be stated that tourist activity of world's and state citizens is constantly growing,

Research shows that different social groups participate in tourist movement. These are people professionally active and passive, with high and low financial and social statutes, diversified by sex and age. Young people with tertiary or secondary education diplomas and income higher than the average are the most eager to travel.

(C) W. Kamińska, M. Mularczyk
Students of institutions of higher education are one of the most commonly travelling groups in touristic purposes in Poland (Łaciak 2013, Lubowiecki-Vikuk, Podgórski 2013). Because of their young age, good health and a considerable amount of free time (Latosińska, Ludwicka 2010) the academic youth chooses tourist destinations with different comfort levels resulting from diversified financial potential. Nevertheless, in general, students do not present high expectations towards tourist (accommodation and food) and transport services. They choose cheaper leisure, compensating potential inconveniences resulting from low prices with a good company and relaxation among friends. Students prefer active leisure during the trips (riding a bike, hiking, water and winter sports) (Kamińska, Mularczyk 2015). They appreciate the clean environment and beautiful landscapes. It means that holiday in an agritourist farms may constitute as an offer well-adjusted to both their needs and financial potential.

Thus, a question arises, what the level of agritourist activity of Polish academic youth is and what the 
significance of trips to agritourist farms is in the whole structure of tourist trips of students. It is an important research problem as students amount to over $4 \%$ of society in Poland.

In the light of the above remarks, the aim of this article is to determine the significance of agritourism in tourist trips of the academic youth in Poland. Specific objectives were formulated as the following questions:

1. How often did students travel in tourist purposes in 2014 ?

2. How often did they choose agritourist leisure?

3. Is there a correlation between total tourist activity and agritourist activity of students?

\section{Research methods}

The primal material was obtained from surveys conducted among 1000 students from 5 academic centres. 712 filled questionnaires were received, 639 of which were qualified for the following research procedure. The research was of preliminary character and was a part of a bigger research project on tourist activity of academic youth in Poland. Students of five institutions of higher education participated in the project. Four of the institutions of higher education were of university character (two with solid reputation: Warsaw University and Maria Curie-Skłodowska University, two with short university traditions - Jan Kochanowski University in Kielce, Kazimierz Pulaski University of Technology and Humanities in Radom) and one was a higher vocational school (The Bronisław Markiewicz State Higher School of Technology and Economics in Jarosław). Women, accounting for $68 \%$ of the total researched group, were the majority in the structure of respondents. Most of the researched were coming from a village (more than a half), then from a big city (over 100 thousand inhabitants) - more than $20 \%$. Almost $26 \%$ of the respondents were permanently registered in small and medium urban centres (up to 20 thousand inhabitants and from 20 to 100 thousand inhabitants). Students represented different academic centres and different fields of study. Majority of students were receiving the education in Kielce. They amounted to more than half of the respondents. Almost one in five respondents studied in Lublin, one in seven in Warsaw. 10\% were the students from Radom, and 4\% from Jarosław.

A vast majority of students declared that net income per 1 family member was low or medium (up to 2 thousand zloty). Net income per one person was on a high level (from 2 to 4 thousand zloty) in the families of one in every five students, and just over $7 \%$ of respondents described it as very high (over 4 thousand zloty).

Students representing different fields of knowledge and scientific disciplines participated in the preliminary research. The law sciences were represented by the students of Administration, social sciences by National Security students, Earth sciences by Geography students, technical, Earth and biological sciences by Spatial Planning students and physical education, economy and Earth sciences were represented by Tourism and Recreation students. It was not a full representation of all scientifiic disciplines, however, as was already mentioned, the presented research was of preliminary character. Almost $1 / 3$ of the respondents were studying Tourism and Recreation, 1/4 Geography and 1/5 National Security. Administration students accounted for more than $15 \%$ and students of Spatial Planning for around $5 \%$.

A non-parametric chi-square test was used to determine a statistical correlation between the total and agritourist activity of the academic youth. Should the statistical correlation be stated between the researched variables, the strength of correlation was determined using a Chuprov coincidence coefficient derived from chi-square statistic (Luszniewicz 1987).

\section{Agritourism in geographical research}

Geographical research on agritourism emerged in the 20th century. A term agritourism was also introduced to the scientific usage in that time as well (Busby, Rendle 2000, McKenzie, Wysocki 2002, Wicks, Merrett 2003).

Research during this period evolved from questions concentrating on defining aspects of agritourism through conditions of its development to the analyses of tourist expectations towards agritourism. These analyses included both theoretical and empirical parts and referred to particular countries and regions.

In studies regarding defining this kind of leisure, an existence of variety of definitions is usually stated. It is said to result from the fact that agritourism relates to activities concerning both tourists as well as the organisers of this kind of leisure (Zoto et al. 2013). Often different terms, such as: agritourism (Barbieri, Mshenga 2008), agrotourism (Kizos, Iosifides 2007), farm tourism (Ollenburg 2006), farm-based tourism (Evans, Ilbery 1989), vacation farms (Weaver, Fennel 1997), are used to describe holiday on an agricultural farm.

Agritourism is usually understood as an additional (next to agricultural) activity conducted on an agricultural farm (Murphy 1985, Carpio et al. 2008, Ilbery et al. 1998) or in a different type of rural surroundings: crops plantations, ranches (Che et al. 2005, Tew, Barbieri 2012) offering tourist services in the broad sense. Leisure in such a place is to provide tourists with contact to rural life, getting to know the details of agricultural farm's functioning and promote cultural heritage of rural areas. Due to this, in many definitions it is stressed that agritourism should be connected to an active agricultural farm (Sonnino 2004, Ollenburg 2006), as only in such farms the quality of tourist's experience can be satisfying and tourists may get a close look/participate in an authentic field work. On the other hand, Fleischer's (et al. 2005) research suggests that from tourist's point of view it is not important whether the farm functions or not. Agritourism may as well be conducted in rural houses especially adapted for this purpose and where shows presenting work connected with food production (e.g. cheese or butter production) may constitute as a part of tourist product (Phillip et al. 2010).

In Poland agritourism is often defined as a form of leisure taking place in the areas of agricultural farms, based on accommodation base and recreation activities connected with an agricultural or similar farms and its surroundings (natural, production and services) (Drzewiecki 2002). G. Spychalski (1998), however, distinguished three basic forms of agritourism: 
- tourism in rural areas, understood as all forms of recreation in a non-urbanised area;

- tourism connected to agriculture, where beside a tourist product, possibilities to acquaint with specifics of farmer profession along with fulfilling some production functions are offered;

- rural tourism which considers the elements of local culture and forms of integration with rural areas society;

In studies, a vast diversification of conditions of agriculture development is pointed out depending on environmental, economic, politic and social and demographic factors. The analysis of characteristics connected to the environment implies that agritourists prefer areas with high diversity of relative altitudes (Maetzold 2002) and seaside areas (Kumbhar 2012). Mainly society's income (Carpio et al. 2008) and revenue of the owners of agritourist farms (Bondoc 2009) are mentioned among economic factors. Economic concepts assume that when income of a particular person is rising, their demand for travelling is most likely to grow (Wang et al. 2006). However, O'Leary et al. (1982) showed that income does not influence tourist behaviour and expectations. Hartman and Cordell (1998), basing on literature review, claimed that people with high income stay in the place of holiday longer than an average tourist and that the travelling distance increases in the group with high income. Nicolau and Mas (2005) claimed that income is a determinant influencing tourist decisions and expectations. The highest income increased the probability of planning another trip (Kattiyapornpong et al. 2009).

The structure of population according to age and sex (Weber 1994, Ashworth, Goodbal 1998) as well as education (Cha et al. 1995) is analysed within social and demographic conditions. Political conditions of agritourism development are also taken into consideration in the subject literature. In this context, a view predominates that in stabilised countries with market economies the pace of development of agritourist farms is much faster than in developing countries (see Carpio et al. 2008, Kumbhar 2012, Eshun, Tettey 2014).

The development of agritourism is highly dependent on demand defined as a sum of tourist goods, services and commodities which tourists are willing to purchase at a particular level of prices (Briggs 2003). Thus, the size of demand strictly relies on the number of tourists and prices of the services provided. In the literature a view predominates that during the following decades the demand for agritourist services will be rising. Carpio (et al. 2008) claims that the heightened interest in agritourism is connected to the increase of demand on outdoor recreation, a growing number of family trips, a growing interest in rural lifestyle and an engagement of local authorities in the development of agriculture.

The demand on agritourist services is estimated differently in studies. Carpio et al. (2008) connected travelling to agritourist farms with the costs of such a trip, income of a household, demographic characteristics and attractions of agritourist destination. Blekesaune et al. (2010) studying agritourism in Norway, distinguished dozen of cultural, social and economic characteristics of visitors which might decide the size of demand on this kind of tourism. Aguilar and Barbieri (2011), however, studying the agritourist activity of people in senior years claimed that it is strongly connected with the distance to the leisure destination.

There is no data describing the real demand on agritourist services in Poland. According to Andrzejewska (1999) almost $80 \%$ of the researched tourists declared the willingness to spend their holidays in rural environment and Kamińska and Mularczyk (2014) claimed that in 2013 agritourist accommodation base was used only in $11 \%$.

Another stream of geographic research concentrated around expectations of tourists toward agritourism. For example Cha et al. (1995), Formica, Uysal (1998), Heung et al. (2001) proved that tourists' expectations were strongly diversified depending on sex, age, size of family and its development phase. Keyser (2002) stressed that age influences the amount of time for leisure and people's inclinations to travel. Period of tourists' highest activity coincides with reaching 40 years of age and then declines with age, but the paste of this decrease is different for both sexes (Unkle 1981, Hartman, Cordel 1989). Jefferson (1991), on the other hand, stated that young people (up to 25 years of age) decide on a longer holiday and stay longer in tourist destinations than an average tourist.

In many studies a thesis was presented that a family's life cycle was one of the most important elements creating tourist behaviour and expectations. For example Wit and Goodale (1981) stated that couples with small children have less time for tourist activity than in other phases of the cycle. Carpio et al. (2008) evidenced a positive correlation between the size of the family with small children and visits in agritourist farms.

In the literature a view could also be found that demographic characteristics cannot constitute a basis for a good tourist market segmentation (Woodside, Pitts 1976, Cheng Lio 2001, Plummer 1974). Lawson (1994) noticed that people with similar demographic characteristics unnecessarily have the same tourist interests. Keng and Cheng (1999) claimed that psychographic characteristics (which include psychological characteristics and life style) are better to use in research on tourist behaviour and expectations. These characteristics reflect the level and kinds of tourist and recreational activities, interests, opinions, personalities and standard of living (Plummer 1974, Blackwell et al. 2001). They influence imagination and perception of tourist experience as well (Speirs 2003).

Expectations of tourists were also diversified by their social and economic characteristics (income, education, occupation, social status).

Cha, Mc Cleary, Uysal (1995) indicated that education was a significant factor influencing motivation and expectations of tourists. According to these authors people travel because they are "stuffed" with their internal needs and "pulled" by the attributes of a tourist destination. The strength of these factors is connected to knowledge and level of education. Zuzanek (1978, cited after: Hartman, Cordell 1989) stated that the index of share in leisure and recreation as well as its spectrum increases almost linearly with the increase of level of education, and the peak of participation in recreation is present among people with the highest level of education. 
Catalino (et al. 2004) claimed that among the demographic and economic characteristics it was the level of education that influenced tourist expectations the most.

There were studies conducted regarding expectations of tourists toward agritourism in Poland as well (Zawadka 2012, 2014, Wilk, Keck-Wilk 2013). The research showed that agritourists expected diversified service offer and prepared with consideration of their individual needs (Wilk, Keck-Wilk 2013). Moreover, they wanted bikes and water equipment rentals in the agritourist farms (Zawadka 2014) and the room should, obligatory, be equipped with a bathroom (Zawadka 2012).

\section{Tourist activity of the academic youth}

In 2014 the researched students participated in total 1775 tourist trips. On average each of the students took part in almost 3 trips. Taking into consideration their free time budget, such an activity should be considered low. The number of declared tourist trips of students ranged between 0 and 15. Taking intensity of participation of the academic youth in tourist movement as a criterion, four groups were distinguished. The first group, with high activity, was represented by students who, during the researched period, participated in more than 6 trips. This group amounted to 69 students which accounted for $11 \%$ of the total. The second group, with average tourist activity, consisted of people who declared participation in 4-6 trips in 2014. Within this group of students, there were 101 people, which constitute $16 \%$ of the researched (Tab 1).

The surveyed characterised by low level of activity, that is participating in trips between 1 and 3 times in the researched year, was the most numerous group. There were 331 of such people, which accounted for almost $52 \%$ of respondents. 138 students, that is almost $22 \%$ of total showed no touristic activity (Tab 1) (Kamińska, Mularczyk 2015a).

\section{Agritourist activity of the academic youth}

Students participated in 362 trips of agritourist character in the analysed period. It constituted $20,4 \%$ of all trips of the students included in the survey research. Moreover, it should be noted that no tourist activity at all was shown by around $22 \%$ of the academic youth while with regard to agritourist activity it was as much as $72 \%$ (Tab 1, Tab 2). It is a sign of students' low interest in the researched form of leisure. The number of declared trips to agritourist farms in 2014 ranged from 0 to 10 . Four groups of students were distinguished. First, characterised by a high agritourist activity (between 6 and 1 trips), second with an average activity (between 2 and 5 trips), third characterised by low activity (1 trip) and fourth

Tourist activity of the academic youth

Table 1.

Tourist activity of the academic youth

\begin{tabular}{|c|c|c|c|c|c|c|c|c|}
\hline \multicolumn{8}{|c|}{ Tourist activity of the academic youth } & \multicolumn{3}{c|}{ none } & \multirow{2}{*}{ low } & \multicolumn{2}{c|}{ total } \\
\hline number of people & $\%$ & number of people & $\%$ & number of people & $\%$ & number of people & $\%$ & \\
\hline 69 & 10,8 & 101 & 15,8 & 331 & 51,8 & 138 & 21,6 & 639 \\
\hline
\end{tabular}

Source: Own calculations

Table 2.

Agritourist activity of the academic youth

\begin{tabular}{|c|c|c|c|c|c|c|c|c|}
\hline \multicolumn{9}{|c|}{ Agritourist activity of the academic youth } \\
\hline \multicolumn{2}{|l|}{ High } & \multicolumn{2}{|l|}{ average } & \multicolumn{2}{|l|}{ Low } & \multicolumn{2}{|l|}{ none } & \multirow{2}{*}{ total } \\
\hline number of people & $\%$ & number of people & $\%$ & number of people & $\%$ & number of people & $\%$ & \\
\hline 8 & 1,25 & 72 & 11,27 & 100 & 15,65 & 459 & 71,83 & 639 \\
\hline
\end{tabular}

Source: Own calculations

Table 3.

Total tourist activity and agritourist activity of students

\begin{tabular}{|c|c|c|c|c|c|c|c|c|c|}
\hline \multirow{3}{*}{$\begin{array}{c}\text { Tourist activity } \\
\text { of students }\end{array}$} & \multicolumn{9}{|c|}{ Agritourist activity of students } \\
\hline & \multicolumn{2}{|c|}{ High } & \multicolumn{2}{|c|}{ average } & \multicolumn{2}{|c|}{ low } & \multicolumn{2}{|c|}{ none } & \multirow[b]{2}{*}{ total } \\
\hline & $\begin{array}{l}\text { number of } \\
\text { people }\end{array}$ & $\%$ & $\begin{array}{c}\text { number of } \\
\text { people }\end{array}$ & $\%$ & $\begin{array}{l}\text { number of } \\
\text { people }\end{array}$ & $\%$ & $\begin{array}{l}\text { number of } \\
\text { people }\end{array}$ & $\%$ & \\
\hline High & 7 & 10,14 & 19 & 27,54 & 4 & 5,80 & 39 & 56,52 & 69 \\
\hline Average & 1 & 0,99 & 25 & 24,75 & 15 & 14,85 & 60 & 59,41 & 101 \\
\hline Low & 0 & 0,00 & 28 & 8,46 & 81 & 24,47 & 222 & 67,07 & 331 \\
\hline none & 0 & 0,00 & 0 & 0,00 & 0 & 0,00 & 138 & 100,00 & 138 \\
\hline Total & 8 & 1,25 & 72 & 11,27 & 100 & 15,65 & 459 & 71,83 & 639 \\
\hline
\end{tabular}

Source: Own calculations 
whose representatives did not avail themselves of leisure in agritourist farms. There were only 8 of the surveyed in the first group, 72 in the second (around 11\%), in the third 100 (around 16\%) (Tab 2).

Students characterised by no agritourist activity were the most numerous set. There were 459 of them, which amounted to almost $72 \%$ of the surveyed. Basing on the presented data, it may be stated that the agritourist activity of students is minor. Only $28 \%$ of the surveyed spent their free time in agritourist farms in the analysed period (Tab 2). People, who chose the researched form of leisure only once during the year, dominated in the group. Considering the fact that spending free time in agritourist farms is one of the cheapest forms of leisure it might have been assumed that it would be more popular among students.

\section{Significance of agritourism in tourist activity} of the academic youth

The tourist activity notably depends on the financial situation of the researched respondents. As research shows (Buchta, Skiert 2007), financial difficulties were more often declared by the students travelling rarely, who were characterised by low and, at most, average tourist activity. Thus, it may be assumed that people using the cheapest forms of leisure, including agritourism, should dominate in this group of respondents.

A non-parametric chi-square test was used to determine a statistical correlation between total tourist activity of students and their agritourist activity. A zero hypothesis was verified, in which no statistical correlation between tourist activity and agritourist activity of students was assumed against an alternative hypothesis assuming such a correlation. As the calculated amount of chi-square $(162,9)$ was much higher than the critical value (from the tables - 16,9 with 9 degrees of freedom, statistical significance 0,05$)$ the zero hypothesis was rejected. The strength of correlation, calculated by Chuprov's test $(0,3)$ was statistically significant. Basing on the calculations, it was claimed that there is a statistical correlation between total tourist activity of students and their agritourist activity.

It was noted, however, that students with the highest total tourist activity were characterised by the highest agritourist activity and not, as assumed, those characterised by low activity. In the first of the groups there were almost $38 \%$ of the surveyed characterised by high and average agritourist activity while in the second there were a little over $8 \%$ of the respondents (Tab 3). Thus, it may be claimed that low price of leisure in an agritourist farm did not cause a higher interest in this form of leisure among less tourist active students.
It was also noted that students with no agritourist activity dominated in all the researched groups. They amounted to more than $56 \%$ of the respondents with high tourist activity, over $59 \%$ of those with an average activity and over $67 \%$ of those with a low activity (Tab $3)$. Thus, it may be stated that agritourism, despite the low price, is not an attractive form of leisure for students. It is used mostly by the students with high total tourist activity.

\section{Conclusions}

The conducted analyses allow formulating the following conclusions:

1. In 2014 an average researched student participated in three tourist trips. Criteria adopted for the purpose of this research allow assessing that tourist activity of the surveyed was at a low level. The fact that one in five of the surveyed did not participate in tourist movement in the researched period proves it as well. It was a value twice higher than the correspondent value received in the research conducted on a similar in size statistical sample in Mikołaj Kopernik University in Toruń (Lubowiecki-Vikuk, Podgórski 2013).

2. In the analysed period, trips to agritourist farms amounted to only $20,4 \%$ of all tourist trips of the surveyed students. Over $70 \%$ of the researched in 2014 did not use agritourist services. Thus, it may be stated that, despite the fact that stay in agritourist farm is one of the cheapest forms of leisure, it is not very popular among Polish students. The earlier research (Kamińska, Mularczyk 2015b) shows that in respect of equipment, agritourist farms are ready to serve students. In majority of cases the owners of the farms enable guests the access to the equipment allowing passive (e.g. a bonfire place, grill) and active (e.g. bikes) leisure expected by the students. Nevertheless, the majority of students is not interested in spending their free time in agritourist farms. The cause of this situation can be ascribed to, among others, poor promotion of agritourism among the researched group of young people, especially internet promotion.

3. It was stated that there is a statistical correlation between total tourist activity of students and their agritourist activity. In this range, the highest activity was shown by the students with the highest total tourist activity. Thesis claiming that a higher interest in agritourism was shown by the students with low tourist activity relative to their peers characterised by a high activity was not confirmed. Thus, it should be stated that a low cost was not a motivating factor to spend free time in agritourist farms more often for students characterised by low tourist activity.

\section{References:}

1. Aguilar F. X., Barbieri C. Preferences for outdoor recreation activities in privately owned forests, public parks and farms in Missouri. Oral presentation at the 92nd Society of American Foresters National Convention (SAF). Honolulu, HI, 2011.

2. Andrzejewska O. Wczasy pod gruszą-agroturystyka w modzie. Rolnictwo, BOSS-Informacje ekonomiczne, 1999, N. 38 (505), Warszawa.

3. Ashworth G., Goodall B. Tourist images: Marketing considerations. In: Goodall B., Ashworth G. (eds) Marketing in the tourism industry: The promotion of destination regions. London: Routledge. Baloglu 1997.

4. Barbieri C., Mshenga P. M. The role of the firm and the owner characteristics on the performance of agritourism 
farms. Sociologia Ruralis, 2008, Vol. 48(2), pp. 166-182.

5. Blackwell R.D, Miniard P.W., Engel J.F. Consumer behavior. Fort Worth, TX: Harcourt College Publishers, 2001.

6. Blekesaune A., Brandth B., Haugen M. S. Visitors to farm tourism enterprises in Norway.Scandinavian Journal of Hospitality and Tourism, 2010, Vol. 10 (1), pp. 54-73.

7. Bondoc I. Finding Fun in Food Farming Characteristics of U.S., Agritourism Industry, University of Florida, 2009.

8. Briggs S. Marketing w turystyce. Translated by G. Górska. Warszawa: Polskie Wydawnictwo Ekonomiczne, 2003.

9. Buchta K., Skiert M. Wzorce aktywności turystycznej studentów turystyki i rekreacji w uczelni wychowania fizycznego, Zeszyty Naukowe Uniwersytetu Szczecińskiego, 2012, N. 699, pp. 23-32.

10. Busby G., Rendle S., 2000, The transition from tourism in farms to farm tourism. Tourism Management, Vol. 21, pp. 635-642.

11. Carpio C. E, Wohlgenant M.K., Boonsaeng T. The Demand for Agritourism in the United States'. Journal of Agricultural and Resource Economics, 2008, 33(2), pp. 254-269.

12. Catalino A.H., Magdalena Lizardo M. Agriculture, Environmental Services and Agro-Tourism in the Dominican Republic. Journal of Agricultural and Development Economics, 2004, Vol. 1, No. 1, pp. 87-116.

13. Cha S, McCleary K.W., Uysal M. Travel motivations of Japanese overseas travellers: A factor-cluster segmentation approach. Journal of Travel Research, 1995, Vol. 34 (1), pp. 33-39.

14. Che D., Veeck A., Veeck G. Sustaining production and strengthening the agritourism product: linkages among Michigan agritourism destinations. Agriculture and Human Values, 2005, Vol. 22, pp. 225-234.

15. Cheng J. S., Lio M., C. A preliminary study on the construction of Taiwanese vacation lifestyle scale a case of the Kenting National Park's Travelers. Journal of Outdoor Recreation Study, 2001, Vol. 14(3), pp. 57-80.

16. Drzewiecki M. Podstawy agroturystyki [Basics of agritourism]. Bydgoszcz: Wydawnictwo OPO, 2002.

17. Durydiwka M., 2009, Ruch turystyczny - z centrum ku peryferiom [Tourist movement: from centre to periphery]. Prace i Studia Geograficzne, T. 42, pp. 59-71.

18. Eshun G, Tettey Ch. Agrotourism development in Ghana: A study of its prospects and challenges at Adjeikrom Cocoa Tour Facility. Bulletin of Geography. Socio-economic Series, 2014, Vol. 25, pp. 81-99.

19. Evans N. J., Ilbery B. W. A conceptual framework for investigating farm-based accomodation and tourism in Britain. Journal of Rural Studies, 1989, Vol. 5, pp. 257-266.

20. Fleischer A., Tchetchik A. Does rural tourism benefit from agriculture? Tourism Management, 2005, Vol. 26, pp. 493-501.

21. Formica S., Uysal M. Market segmentation of an international cultural-historical event in Italy. Journal of Travel Research, 1998, Vol. 36 (4), pp. 16-24.

22. Hartmann L.A., Cordell H.K. An Overview of the Relationship Between Social and Demographic Factors Outdoor Recreation Participation, General Technical Report SE-52, [in:] A.E. Watson (ed.), Outdoor Recreation Benchmark, 1988, pp. 255-274.

23. Heung V.C.S., Qu H., Chu R. The relationship between vacation factors and $\backslash$ sociodemographic and travelling characteristics: The case of Japanese leisure travellers. Tourism Management, 2001, Vol. 22, pp. 259-269.

24. Ilbery B., Bowler I., Clark G., Crockett A., Shaw A. Farm based tourism as an alternative farm enterprise: a case study from the Northern Pennines, England. Regional Studies, 1998, Vol. 32 (4), pp. 355-364.

25. Jefferson A. Demographics, youth and tourism. Tourism Management, 1991, Vol. 12 (1), pp. 73-75.

26. Kamińska W., Mularczyk M., Occupancy rate of accommodation in Poland. Geologiâ, geoèkologiâ, èvolûcionnaâ geografiâ [Geology, geoecology, evolutionary geography], N. XIII, Herzen University, St. Petersburg, 2014, pp. 260-268.

27. Kamińska W., Mularczyk M. Preferowane formy wypoczynku młodzieży akademickiej znaczenie rowerów i ścieżek rowerowych. Wyniki badań ankietowych, [w:] W. Kamińska, M. Wilk-Grzywna (red.), Uwarunkowania rozwoju turystyki aktywnej na obszarach wiejskich, Studia KPZK PAN, T. CLXVI, Warszawa, 2015, pp. 81-98.

28. Kamińska W., Mularczyk M. Development of agritourism in Poland: a critical analysis of students` expectations of agritourism farms. Miscellanea Geographica, 2015b, Vol. 19, N. 4.

29. Kattiyapornpong U., Miller K. E. Understanding Travel Behavior using Demographic and Socioeconomic Variables as Travel Constraints. Journal of Culture Tourism and Hospitality Research, 2009, Vol. 3, N. 1, pp. 84-94.

30. Keng K.A., Cheng J.L.L. Determining tourist role typologies: An exploratory study of Singapore vacationers. Journal of Travel Research, 1999, Vol. 37, pp. 382-390.

31. Keyser H. Tourism development. Cape Town: Oxford University Press, 2002.

32. Kizos T., Iosifides T. The contradictions of agrotourism development in Greece: Evidence from three case studies. South European Society \& Politics, 2007, Vol. 12 (1), pp. 59-77.

33. Kumbhar V.M. Tourist Expectations Regarding Agritourism. Empirical Evidence from Ratnagiri and Sindhudurg District of Konkan (Maharashtra). Online International Interdisciplinary Research Journal, 2012, Volume-II, Issue-III, pp 82-91.

34. Latosińska J., Ludwicka D. Aktywność turystyczna młodzieży akademickiej na przykładzie wyższych uczelni w Lodzi. Turyzm I, 2010, pp. 21-28. 
35. Lawson R. Demographic segmentation, [in:] Witt S.F., Moutinho L., (eds) Tourism marketing and management handbook 2nd ed, London: Prentice Hall, 1994, pp. 311-315.

36. Lubowiecki-Vikuk A.P., Podgórski Z. Zachowania i preferencje turystyczne młodzieży akademickiej, [w:]: R Pawlusiński (red.), Współczesne uwarunkowania i problemy rozwoju turystyki. Kraków: IGiGP, UJ, 2013, pp.149-158.

37. Luszniewicz A. Statystyka ogólna. PWE, Warszawa, 1978.

38. Łaciak J. Aktywność turystyczna mieszkańców Polski w wyjazdach turystycznych w 2012 roku. Warszawa, 2013.

39. Maetzold J. (2002): Nature-based tourism \& agritourism trends: unlimited opportunities. www.kerrcenter. com/publications/2002_ proceedings/agritourism.pdf.12/08/2009.

40. McKenzie N., Wysocki A. (2002): Agritainment: A viable option for Florida producers [pdf]. Retrieved from: http://www.doc88.com/p-6963130585751.html, access on: 20 May, 2016.

41. Murphy P. E. Tourism: A Community Approach. New York, NY: Methuen, 1985.

42. Nicolau, J.L., Más, F.J. Heckit modelling of tourist expenditure: Evidence from Spain, International Journal of Service Industry Management, 2005, Vol. 16, N. 3, pp. 271-293.

43. O'Leary J.T., Napier T.L., Dottavio F.D., Yoesting D., Christensen J. Examining Predictor Variables Used in Outdoor Recreation Planning, [in:] Countryman, Guiding Land Use Management, John Hopkin`s University Press, Baltimore, 1982, pp. 140-149.

44. Ollenburg C. (2006): Farm tourism in Australia: a family business and rural studies perspective [pdf]. Retrieved from: http://www120.secure.griffith.edu.au/rch/file/9e67d3aa-4eb1-af60 eee0c07c3e5d7b90/1/01Front.pdf., access on: 20 May, 2016.

45. Phillip S., Hunte C., Blackstock K. A typology for defining agritourism. Tourism Management, 2010, Vol. 31, N. 6, pp. 754-758.

46. Plummer J. T. The concept and application of lifestyle segmentation. Journal of Marketing, 1974, Vol. 38 (1), pp. 33-37.

47. Sonnino R., 2004, For a 'piece of bread'? Interpreting sustainable development through agritourism in Southern Tuscany. Sociologia Ruralis, 44(3): 285-300.

48. Speirs L.J., 2003, Agritourism: market segmentation profile of potential and practicing agrotourists, Stellenbosch Univeristy.

49. Spychalski G., 1998, Agroturystyka jako element przedsiębiorczości pozarolniczej na obszarach wiejskich [Agritourism as an element of non-agricultural entrepreneurship in rural areas] (pp. 243-250). In L. Pałasz (Ed.), Agrobiznes - pozarolnicze przedsięwzięcia gospodarcze na obszarach wiejskich [Agribusiness - non-agricultural economic acticities in the rural areas]. Szczecin: Wydawnictwo Akademii Rolniczej.

50. Tew C., Barbieri C., 2012, The perceived benefits of agritourism: the provider's perspective. Tourism Management, 33(1): 215-224.

51. Unkle M.B. 1981. Psychical Recreation Partycipation of Females and Males During the Adult Life Cycle. Leisure Sciences. 4(1), p. 1-27.

52. Witt, P.A., and Goodale, T.L., 1981. The relationship between barriers to leisure enjoyment and family stages. Leisure Sciences 4, 29-49.

53. Wang, Y., Rompf, P., Severt, D., \& Peerapatdit, N. (2006). Examining and identifying the determinants of travel expenditure patterns. International Journal of Tourism Research, 8(5), 333-346.

54. Weaver D. B., Fennell D. A. The vacation farm sector in Saskatchewan: a profile of operations. Tourism Management, 1997, Vol. 18, pp. 357-365.

55. Weber S. Psychographic segmentation. In: S. F.Witt, L. Moutinho (eds), Tourism Marketing and Management Handbook, New York, 1994, pp. 316-320.

56. Wicks B. E., Merrett C. D., 2003, Agritourism: An economic opportunity for Illinois. Rural Research Report, 14(9): 1-8.

57. Wilk I., Keck-Wilk M. Oczekiwania turystów dotyczące oferty gospodarstw agroturystycznych. Journal of Agribusiness and Rural Development, 2013, Vol. 2(28), pp. 243-250.

58. Woodside A.G., Pitts R.E., 1976, Effects of consumer lifestyles, demographics and travel activities on foreign and domestic travel behaviour. Journal of Travel Research 14: BIS.

59. Zawadka J. Preferencje turystów dotyczące wypoczynku w gospodarstwach agroturystycznych na Lubelszczyźnie. Zeszyty Naukowe Uniwersytetu Szczecińskiego. Ekonomiczne Problemy Usług, 2012, N. 699, Szczecin, pp. 167-179.

60. Zawadka J. Zachowania i oczekiwania turystyczne osób wypoczywających na wsi w kontekście infrastruktury okołoturystycznej. In: C. Jastrzębski (red.), Agrotravel 2014, ROT, Kielce, WSWPiNM, Kielce.

61. Zoto S., Qirici E., Polena E. Agrotourism - A sustainable development for rural area of Korca. European Academic Research, 2013, Vol. 1 (2), pp. 209-223.

62. Zuzanek J. Social differences in leisure behavior. Measurement and interpretation. Leisure Sciences, 1978, Vol. 1 (3), pp. 271-293. 